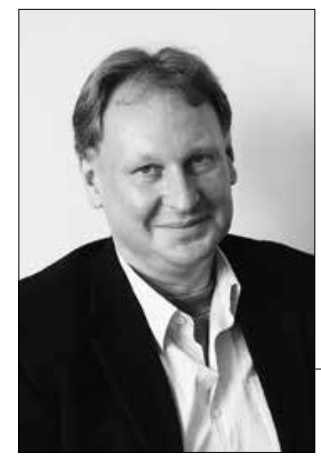

https://doi.org/10.24101/logos.2020.37

Gauta 20200227

TOMAS KAVALIAUSKAS

Vytauto Didžiojo universitetas, Lietuva

Vytautas Magnus University, Lithuania

\title{
MENO FILOSOFIJA: DAUGIASLUOKSNE DOGU BANKOVO BIOGRAFIJA
}

\author{
Art Philosophy: The Multi-Layered Biography of Dogu Bankov
}

\author{
SUMMARY
}

This article aims to disclose art philosophy, which is behind the literary story and collage pictures of the Bulgarian artist, Dogu Bankov. The author of this article analyzes the relationship between the narrative about Dogu Bankov in literature and in the visual arts, namely, in the exhibited pictures in the collage genre, and in the multi-layered, highly cosmopolitan biography of Dogu Bankov. Topophilia in Paris, also in Bulgarian town Plovdiv, and in Lithuanian town Kaunas is an inseparable part of Bankov's biography along with the documentary resurrection of true interwar intellectuals of those cities. The biography serves as a plethora of cross-cultural references to true writers and artists even if the biography of Bankov is artistically created.

\section{SANTRAUKA}

Straipsnyje siekiama atskleisti meno filosofiją, slypinčią už literatūrinės istorijos ir koliažų paveikslų, priskiriamų bulgarų menininkui Dogu Bankovui. Straipsnyje analizuojamas santykis tarp D. Bankovo naratyvo literatūroje ir vizualiuosiuose menuose, būtent eksponuotuose koliažuose, tiriama biografija, kuri yra itin kosmopolitiška. Topofilija Paryžiuje, Bulgarijos Plovdivo mieste ir Lietuvoje, Kaune, yra neatsiejama Bankovo biografijos dalis, kartu dokumentiškai prikeliant realius tarpukario intelektualus. Biografinès detalès vertingos kaip tarpkultūrinès nuorodos į realius rašytojus bei menininkus, net jeigu Bankovo biografija ir yra meniškai sukurta.

\section{INTRODUCTION}

This article aims to disclose art phi- story and collage pictures of a Bulgarian losophy, which is behind the literary artist Dogu Bankov. This article will have 
its sequence, because the scope for the analysis of the relationship between biographical narrative about Dogu Bankov and his pictures, is larger than one article. The analysis is divided into three dimensions: the first dimension - the multi-layered biography of Dogu Bankov; the second dimension - the dialectics of the original picture and its fake; the third dimension - collage pictures as indirect illustrations to classic literature. However, this article is devoted only to the analysis of the first dimension - the biographical part, which is highly cosmopolitan. The other dimen- sions will be analyzed in a separate article of this journal.

Topophilia in Paris, also in Bulgarian town Plovdiv, and in Lithuanian town Kaunas is an inseparable part of Bankov's biography along with the documentary resurrection of true interwar intellectuals of those cities. Real people and places like streets and cafes that existed in reality in 1920s and 1930s are combined with invented events and characters. The biography of Dogu Bankov serves as a plethora of cross-cultural references to true writers and artists even if the biography itself is artistically created, even invented.

\section{THE MULTI-LAYERED BIOGRAPHY OF DOGU BANKOV}

Let us start with the question: did Dogu Bankov exist at all? If his biography is invented, then was the biography invented for a person who never existed or for a person whose biography is different? The person as such seems to have existed, because the curator of Dogu Bankov exhibitions, Gøran Ohldieck, in an interview to Rytis Zemkauskas in a documentary film "Almost totally unknown artist" said that he personally found by pure chance a collage picture signed by Dogu Bankov in a flea market in Sofia, Bulgaria (Zemkauskas 2011). Moreover, in the back of the picture he found a photo of him standing together with the classmates from Sofia's Art Academy in 1910. However, this is about all that we know about the existence of this Bulgarian artist.

His last name is very common in Bulgaria; therefore, it does not say much. His first name is more Macedonian, than
Bulgarian, and seems to have been used by local Muslim families in 1880s. The biographical traces have disappeared. The date of death is unknown, although the Bulgarian Embassy in Budapest, Hungary, seems to have contributed financially to the funeral of a Bulgarian person, who had this name in the year 1970. It is not known if this is the same Dogu Bankov. Nor the exact date of birth is known. In spite of this, Dogu Bankov's biography accompanied with his list of oeuvres of an artist is exceptionally prolific. Naturally the question is: where does it all come from? What is the source of Dogu Bankov's biography? More importantly, what is the source of his picture collections and numerous exhibitions that a few times included a hundred pictures and once included as many as three hundred pictures? The three hundred picture exhibition was dedicated to Petronius "Satyricon", pic- 
tures serving as indirect illustrations to the text. Another a hundred picture exhibition was dedicated to Federico Garcia Lorca's play "The Public", also as indirect illustrations to the text. A hundred fifty picture collection was exhibited together with the memoirs by Agnes Schaunegger, a cook, who described the events in Paris cafe L'Ane Rouge where Dogu Bankov and Bulgarian emigre artists used to meet. According to these memoirs, Bankov created his collage pictures in this cafe, often inspired by various events and personalities.

This is where the biography of Dogu Bankov develops and supposedly reaches its peak - in the Paris cafe L'Ane Rouge. ${ }^{1}$ The word "supposedly" is not coincidental, because here starts the invented narrative. But the invented narrative on the biography of Bankov is based on the idea that his life of an artist could have developed in such a way. The principle could have is based on two ideas: the first is that Bankov, who had education in Sofia's Art Academy and who had produced a collage picture, could have continued his artist career namely in the genre of a collage, with time making them better and better; the second idea is that Paris at the time had many Bulgarian emigres, thus, he could have been one of them. The pictures made by Bankov contain Paris interwar periodicals, namely clippings from various journals, newspapers or posters. Sometimes one can detect elements of Bulgarian origin, like a pack of cigarettes or Bulgarian newspapers.

This principle of "could have" contains historic logic - Bankov, who could have lived in Paris, indeed could have used that particular material for his collage pictures, namely clippings from periodicals of 1920s and 1930s. The historic logic opens the possibility for documentary. Suddenly we are no longer on the ground of pure fictional and invented biography. Suddenly here is the realization that fiction can be interwoven with documentary. The imagination of the one, who invented Bankov's biography, is mixed with the real documentary artifacts which could have been used if the story were true. Thus, just like in literature novel there are stories that appeal to the reader because they sound so convincingly, by the same token, the life story according to the memoirs of the cook Schaunegger also sound as if it were true.

Needless to say, the cook, who supposedly watched Bankov closely and described him and his work style in her memoirs, is a personage herself. But the book, titled "Dogu Bankov: Don't Shoot the Waiter before Lunch", provides her texts as excerpts in the genre of memoirs. These excerpts are provided as explanatory texts for the collage pictures. Or vice versa - perhaps the pictures are indirect illustrations to the memoirs of the cook. It contains the moments of vivid and entertaining life inside the L'Ane Rouge cafe: marriage, flirting, prostitution, intellectual conversations, habits of the regular clients, cooking recipes, discussion about food.

As we see, the first voice narrative of the cook provides the illusion of a true documentary memoir. It opens the windows into the inner world of the interwar Paris cafe. This approach is fundamental for the establishment of Bankov's biography. This is the main source, whereas the true author of these memoirs could be someone else. 
The book, titled "Dogu Bankov: Don't Shoot the Waiter before Lunch", was published in Lithuania in 2011 by M.K. Čiurlionis National Art Museum (Bankov 2011). This museum has arranged a number of the most fundamental Bankov's exhibitions in Kaunas in its gallery of Žilinskas. In the year 2017 the Museum organized launching for the public a literature book in the genre of a novel by the author of this article. The novel titled "Originalas" [The Original], which tells the story about Dogu Bankov and his curator (Kavaliauskas 2017). The novel is by its genre fictional, therefore, the reader is aware that biography details about Bankov could be invented, but the other book that was already mentioned “Dogu Bankov: Don't Shoot the Waiter before Lunch" - nowhere says that it is fictional, rather it is portrayed as documentary in the genre of memoirs written by the cook of cafe L'Ane Rouge (Bankov 2011). In addition, the first opening pages are supposedly written by art experts. One of them is Carl Th. Weiner, German origin Argentinian art curator who has worked with Dogu Bankov's collections. It is of interest that a very large Bankov's exhibition was shown in Buenos Aires. ${ }^{2}$ Not coincidentally Carl Weiner becomes the main personage in the novel "Originalas" [The Original] (Kavaliauskas 2017). As we learn reading the novel, Carl Weiner, as a character, is Alpha and Omega of Dogu Bankov's picture collections, their restorations, and biographical stories. Without Weiner the character of Bankov and his story would fade. Carl Weiner, as a curator of Bankov's exhibitions, is a part of a detective story. He travels to Bulgarian town Plovdiv in search for missing pictures. It is Carl
Weiner who makes the story colourful. Dogu Bankov is just a pretext for intellectually entertaining adventure in the colourful fields of art.

According to the story-line, Carl Weiner lives in Kaunas, Lithuania, and being in a great relationship with the director of M. K. Čiurlionis National Art Museum, successfully exhibits Dogu Bankov's collections, supposedly restored. He tells that his challenge is to restore some of the damaged pictures, for the restoration sometimes he travels to Sofia's antique shops where he searches for needed details, interwar publications. The story-line also includes his fictional Bulgarian competitor Goran Goranov, who in Bulgarian city Plovdiv works as a director of the local art gallery, and his assistant, Vera Sotnikova, who is an imposter of a daughter of a historically true Vera Sotnikova, who lived in Kaunas during interwar and was a Lithuanian Russian-Jewish, theatre expert, also a girlfriend of Finnish-Swedish writer Henry Parland, who at the time resided in Kaunas. Henry Parland and Vera Sotnikova as the intellectuals of Kaunas in 1930s are resurrected in a documentary fashion, but then their life stories are interwoven with Dogu Bankov in a fictional way - supposedly Dogu Bankov and Henry Parland exchanged letters from Kaunas to Paris for both of them were interested into theatre - one being a writer (in the case of Parland), the other being a visual artist (in the case of Bankov).

Thus, interwar Helsinki (the native place of Parland), Kaunas (the place for Parland's creative residence where he meets his girlfriend Vera Sotnikova and 
lives in the house of a famous philosopher Vasyli (Vasilius) Sesemann), Paris (the place for Bankov's creative residence where he meets his patron Russian-Jewish Amchiel Goldstein, an uncle of Vera Sotnikova (this is how she learns about Bankov in Paris and tells to Parland)), Sofia (the place of Bankov's studies at the Art Academy before he emigrates), Plovdiv (the town where some Bankov's pictures are kept in the 21s century) become all interrelated.

The novel "The Original" is narrated from the perspective of the $21^{\text {st }}$ century by a young doctoral student from Kaunas Art Faculty at Vytautas Magnus University. As he learns from the curator Carl Weiner about Bankov's biography, the reader gets references to the memoirs of Shaunegger leaving the impression that the memoirs do exist and serve as the original source on Bankov's life story. However, the memoirs as the genre could be used as a fiction narrative as well, but strengthening the impression of the supposedly provided true, documentary-based story.

The cafe L'Ane Rouge in Paris existed. It also appears in documentary photography. ${ }^{3}$ By the same token, the first person narration we also see in the book "Dogu Bankov: Don't Shoot the Waiter before Lunch", where the first person narration is penned by the cafe's cook. That seduces the reader at least for a moment to consider the possibly that the memoirs are the true memoirs:

Sometimes Bankov would be very excited about something he had found on the street or in the garbage. Very often these things would appear in his pictures, which nobody liked, maybe apart from
Goldstein who was actually buying these things for money. ${ }^{4}[. .$.$] One day it was$ announced that Bankov was to have an exhibition (Bankov 2011: 13).

It is also important to underline that the multi-layered story of Dogu Bankov is based not only on the documentary of 1920s and 1930s, but also on a contemporary documentary that was created additionally in the $21^{\text {st }}$ century in order to promote the discourse of Dogu Bankov: the documentary film about the case of Dogu Bankov that includes interviews with artists and administration from M. K. Čiurlionis National Art Museum as well as a Bulgarian ambassador and a Bulgarian art expert (Zemkauskas 2011); numerous factual exhibitions in the name of Dogu Bankov that were exhibited in Kaunas, Lithuania: 1. "Don't Shoot the Waiter before Lunch" (2010, Žilinskas Art Gallery, M. K. Čiurlionis National Art Museum) 2. "Romeo could be a Grain of Salt, Juliet could be a Map" (2015, Žilinskas Art Gallery, M. K. Čiurlionis National Art Museum) 3. "War Requiem" (2018, Devil's museum, M. K. Čiurlionis National Art Museum) 4. "300 pictures to Satyricon" (2020, Žilinskas Art Gallery, M. K. Čiurlionis National Art Museum (without an artist's name, however, due to style, composition, material of the collage, provides sufficient reasons to include to the list) $) ;{ }^{5}$ journalistic reportage of the exhibition openings on Lithuanian national TV news which included interviews with the museum administration and the curator of the exhibitions; Gregorijus Kanovičius literature prize award for the best cosmopolitan novel of the year, "Originalas" [The Original] about the story of Dogu 
Bankov (Kavaliauskas 2017); reviews of the exhibitions of Dogu Bankov in cultural weekly newspaper Šiaurès Atėnai [Northern Athens] (Jacytė 2015) as well as in local daily newspaper Kauno diena [Kaunas' Day] (Milkova 2010).

The reviews have a special place in the discourse of Dogu Bankov, because they demystify the story. Aistè Jacyte titled her review "The Invented Artist". The review itself is about Dogu Bankov's exhibition in Kaunas Žilinskas gallery, titled “Romeo could be a Grain of Salt, Juliet could be a Map," - the words taken from Lorca's play "El Publico", in English known as "The Public", although a more correct translation could be "The Audience". Jacyte says the following words:

Why is my text titled "The Invented Artist?“ [...] D. Bankov (who supposedly lived 1884-1970) - is not a nickname of G. Ohldieck, but rather a fictional person, an artist of a Bulgarian origin; according to carefully placed biographical facts, he had a number of colorful friends in Paris at the beginning of the $20^{\text {th }}$ century where he lived and created. In one of his interviews about the idea to invent a fictitious person G. Ohldieck stated:

'Art works have a right to exist independently, why should I be introduced next to the pictures? Besides, I do not hide. I simply do not wish to advertise myself. If I had to play a piano, then it would be a different matter, because I would not have a choice to be invisible, not to be present.' [...] An artist created another artist, then the latter one created objects, which are extended by the interpretations of a spectator. A never ending process (Jacytè 2015).

On the other hand, Jacyte in her review is concerned with the idea of the creation of another artist and his biography, rather than demystification for the sake of it, although, as the title of the review indicates, it includes that as well. Her review is not a typical report of a journalist, who alarms society about forgery, but an intellectual analysis of the technique and the ideas that she found behind the surface of the pictures, including Bankov's biography.

Five years before this review was published, Lithuanian daily Kauno diena [Kaunas Day] published a review of another Dogu Bankov's exhibition. The exhibition was titled "Don't Shoot the Waiter before Lunch", which included 152 collage pictures with explanations by the cafe L'Ane Rouge cook Agnes Schaunegger. The review by Vaida Milkova was titled "The Exhibition of a Really Unrealistic Dogu Bankov" (Milkova: 2010).

She shared her impressions as follows: "By going through the exhibition all the time the feeling was that the works were created considerably later than 1920s or 1930s [...] The suspicion is that Dogu Bankov is merely an artistic fiction" (Milkova 2010).

Needless to say, there is no data provided by sociologists on how many exhibition visitors actually believe in the biography and authenticity of Dogu Bankov's works. There is no such a thing as a survey with a question: "Do you believe that Bankov's biography is real or do you believe it is an artistic fiction?" However, it is very likely that the majority also believes in his authorship, just as the above-mentioned reader, who admitted in his conversion into the belief of Bankov's existence. 
It is a documentary reality that Dogu Bankov's pictures were exhibited in Bulgaria, Plovdiv's City Art Gallery. It is a historic fact that some of Bankov's pictures of that exhibition were not returned after the exhibiting period. Here nothing is invented. After the curator Gøran Ohldieck in real life (not to be confused with the curator Carl Th. Weiner, who appears in the novel "The Original" as a character, although they may share the same mission) made his investigation in 2011, the City Art Gallery of Plovdiv agreed to return those "withheld" pictures back to M. K. Čiurlionis National Art Mu- seum, however, the Bulgarian Ministry of Culture blocked it.The Bulgarian Ministry of Culture sent an official letter to M. K. Čiurlionis National Art Museum stating that Dogu Bankov's pictures are national heritage of Bulgaria, therefore, will remain in Bulgaria. Indeed, there was a period when a couple of Dogu Bankov's pictures were exhibited in Sofia's Foreign Art Gallery in the section of Paris school to which also belong such artists as Georgi Papazov (Georges Papasoff) (1894-1972) and Julius Pincas (Jules Pascin) (1885-1930). The latter also worked with collage in Paris in 1920s.

\section{CONCLUSIONS}

The principle of "could have" contains historic logic - Bankov, who could have lived in Paris, indeed could have used that particular material for his collage pictures, namely clippings from periodicals of 1920s and 1930s. The historic logic opens the possibility for documentary. Suddenly we are no longer on the ground of pure fictional and invented biography. Suddenly here is the realization that fiction can be interwoven with documentary. The

\section{References}

Bankov Dogu. 2011. Don't Shoot the Waiter before Lunch. Kaunas: M. K. Čiurlionis National Art Museum.

Cavling Henrik. 1899. Paris. Skildringer fra det moderne Frankrig. Københaven Publisher: Gyldendalske Boghandels Forlag.

Jacytė Aistè. 2015. Išgalvotas menininkas [The Invented Artist]. Šiaurès Atènai [Northern Athens]. Available at: http://www.satenai.lt/2015/ 06/12/isgalvotas-menininkas/ (Visited on February 25,2020 )

Kavaliauskas Tomas. 2017. Originalas [The Original]. Vilnius: Alma Littera. imagination of the one, who invented Bankov's biography, is mixed with the real documentary artifacts which could have been used if the story were true.

The multi-layered story of Dogu Bankov is based not only on the documentary of 1920s and 1930s, but also on a contemporary documentary that was created additionally in the $21^{\text {st }}$ century in order to promote the discourse of Dogu Bankov.

Milkova Vaida. 2010. Realiai nerealaus Dogu Bankovo paroda [The Exhibition of a Really Unrealistic Dogu Bankov]. Kauno diena [Kaunas's Day]. Available at: https://m.kauno.diena.lt/ naujienos/menas-ir-pramogos/realiai-nerealausdbankovo-paroda-182196 (Visited on March 5, 2020)

Zemkauskas Rytis. 2011. Documentary film: Niekam nežinomas menininkas [An (almost) totally unknown artist]. Alchemija XVII. Available at: https://vimeo.com/23816536 (Visited on September 20, 2019) 


\section{Endnotes}

${ }^{1}$ It should be mentioned that the Danish writer Henrik Cavling in his book about Paris tells about L'Ane Rouge cafe, where valuable artworks can be seen on the walls (Cavling 1899).

2 Exhibition "Dogu Bankov" in Centro Cultural Recoleta, Buenos Aires, 2000.

${ }^{3}$ Henrik Cavling (Paulus Olsen) (1858-1933) was called Denmark's first journalist. He wrote a number of books from Paris, London, Greece, the U S A, and the West Indies. The photo of the cafe L'Ane Rouge can be found in the book "Paris" (Cavling 1899).

${ }^{4}$ It is important to mention that in reality the pictures of Dogu Bankov are not for sale. They belong to M. K. Čiurlionis National Art Museum.

${ }^{5}$ It should be mentioned that two more collage projects of this kind exist unsigned and to be exhibited: 100 picture collection as indirect illustrations or simply as "pictures to" "Querelle de Brest" by Jean Genet. The pictures in their style are closer to the pictures to those that are devoted to Lorca's play "The Public" than to the collection of "Satyricon", but much more tragic than in any other Bankov's art work. Querelle is never shown, but indicated by blue stripes a la Breton. The other project is "Homage a Serge Lifar - Composed, Created, Constructed and Controlled Movements." The pictures are of different size and they are to be put together 2, 3 or 4 to form one picture, which Bankov has never been known to do so elsewhere. Also the style has simplicity that would indicate that this must have been his latest project - if at all by him.

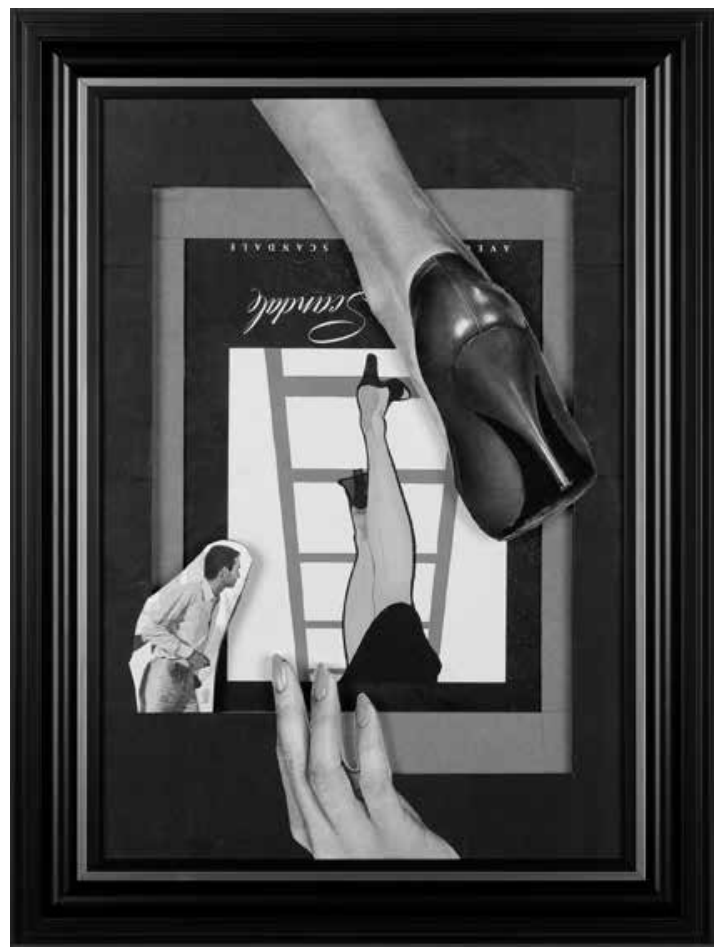

These five pictures on pages 157-158 belong to the collection titled "Romeo could be a Grain of Salt, Juliet could be a Map", artist Dogu Bankov. The collection was exhibited in 2015 May 8th at M. Žilinskas gallery of M. K. Čiurlionis National Art Museum, Kaunas, Lithuania. The collection is dedicated to Federico Garcia Lorca's theatre play "The Public" as indirect illustrations. 

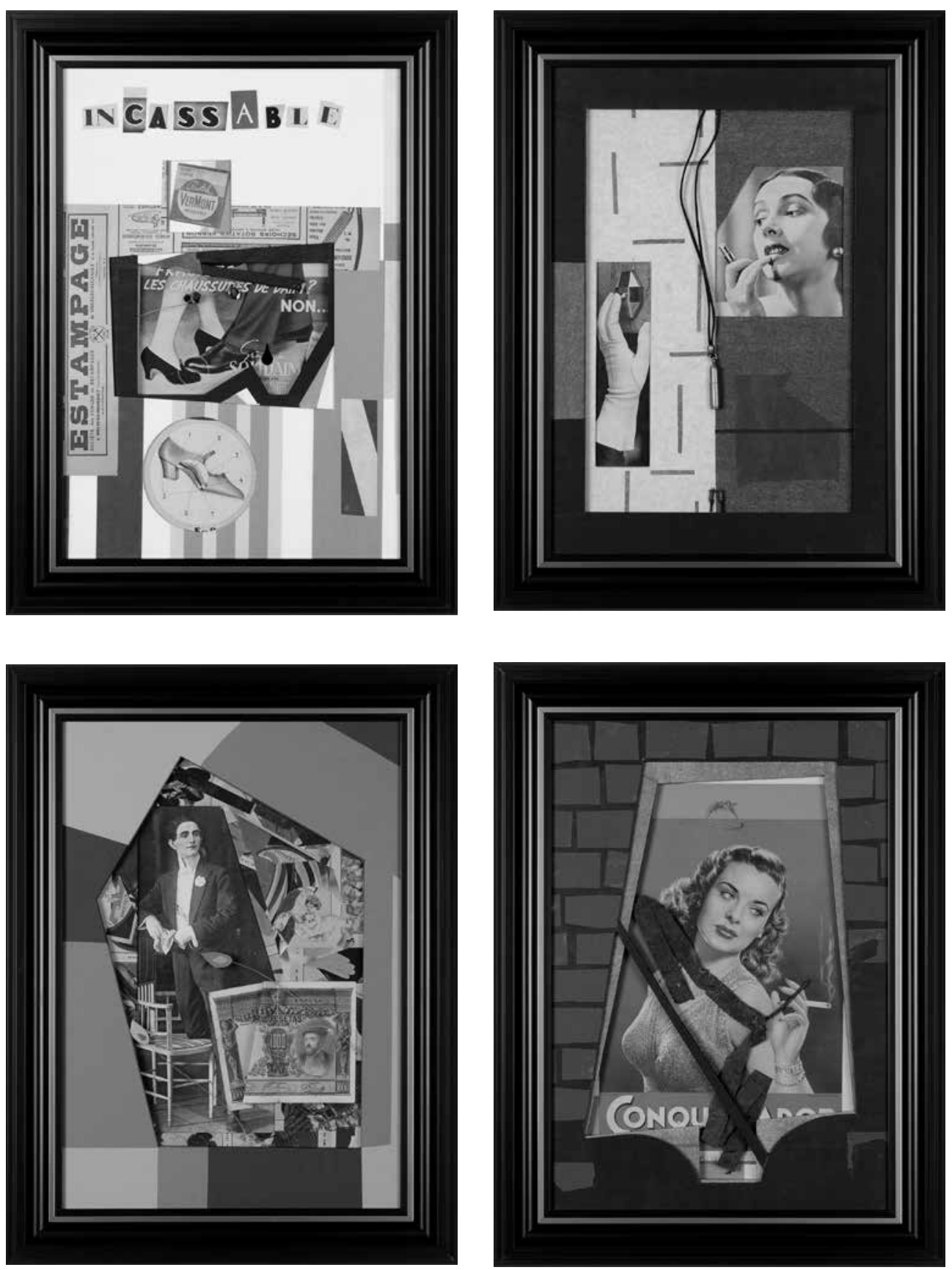